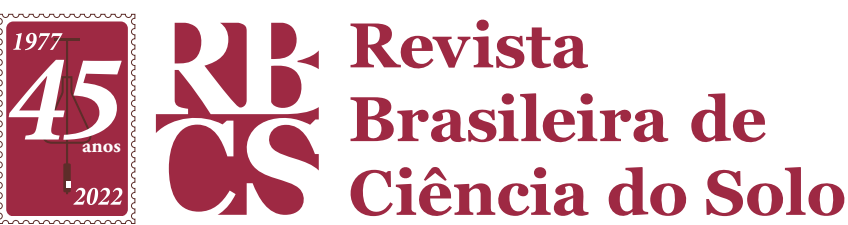

Division - Soil Processes and Properties | Commission - Soil Physics

\title{
Best tillage practices for eucalyptus growth and productivity: A review on the Brazilian experience
}

\author{
Kristiana Fiorentin dos Santos $^{(1)^{*}}$ (D) and José Miguel Reichert ${ }^{(2)}$ \\ (1) Universidade Federal de Santa Maria, Departamento de Engenharia Florestal, Programa de Pós- \\ Graduação em Engenharia Florestal, Santa Maria, Rio Grande do Sul, Brasil. \\ (2) Universidade Federal de Santa Maria, Departamento de Solos, Santa Maria, Rio Grande do Sul, Brasil.
}

* Corresponding author:

E-mail: kristianafiorentin@gmail.com

Received: August 02, 2021

Approved: November 11, 2021

How to cite: Santos KF, Reichert JM. Best tillage practices for eucalyptus growth and productivity: A review on the Brazilian experience. Rev Bras Cienc Solo. 2022;46:e0210091 https://doi.org/10.36783/18069657rbcs20210091

Editors: Reinaldo Bertola Cantarutti (D) and Edivan Rodrigues de Souza (1).

Copyright: This is an open-access article distributed under the terms of the Creative Commons Attribution License, which permits unrestricted use, distribution, and reproduction in any medium, provided that the original author and source are credited.
ABSTRACT: Commercial eucalyptus forestry has significantly increased in the last decades to supply the growing demand for forest goods (pulp, paper, sawmill, by-product industries, and biomass for bioenergy and biofuels). Among factors most influencing forest productivity, the soil physical environment is very important and can be harmful or beneficial to trees. In the effort to increase environmental and economic sustainability of commercial plantations, in this literature review, we summarize relationships between soil type and properties, forest rotation, and forest growth and productivity. Mechanized soil tillage must consider soil type, particularly land slope, soil drainage and depth, along with forest rotation (first or higher-order). Soil surveys, including soil physical properties (e.g., compaction, granulometry including gravel) and morphological attributes (e.g., horizons, solum depth, subsurface drainage impedance), are thus essential for foresters to make knowledgeable decisions on soil tillage, provided tillage is the single most costly practice in eucalyptus forestry. Subsoiling is the most common soil tillage for eucalyptus, but it is best for deep, drained soils. Existing scientific publications show, for clayey cohesive or compacted soils, tillage depth might be of $0.70 \mathrm{~m}$ (deep subsoiling) to ameliorate compacted soil of low microporosity and restriction to root growth, but $0.50 \mathrm{~m}$ (shallow) subsoiling plus ridding produce similar results. The latter, nonetheless, has a higher operational cost. Downslope subsoiling on sloppy lands increases the risk for soil erosion, which may be reduced by interrupting ripping, mechanized hole- or pit-drilling with low operational cost. Chiseling performed for fertilizer application (minimum $0.25 \mathrm{~m}$ deep) might be the only tillage required for non-compacted sandy soils. Mechanical or manual pitting could also be an option for second or higher rotations, but results show crop early-growth is restricted, possibly because of root confinement. For second or higher rotations, stumps require cutting to allow cross-slope tractor traffic and tillage. Subsoiling plus ridging or bedding is required in low-drainage or shallow soils to increase the soil volume to be explored by roots. The ridges can be built by grade bedding or terracing plows. In areas with waterlogging, drainage and ridging without subsoiling are necessary. Research opportunities include further studies for slopy lands and low-drainage or compacted soils, tillage affecting soil erosion and eucalyptus productivity, equipment for special tillage, and mapping compaction risk and special tillage needs.

Keywords: Eucalyptus forestry, soil tillage, soil compaction, subsoiling, pit-drilling tillage. 


\section{INTRODUCTION}

Eucalyptus plantations are increasing in several parts of the world because of edaphoclimatic adaptation and diverse uses of the raw materials derived from eucalyptus (Gonçalves et al., 2013). Offering an alternative supply of wood, thereby reducing the pressure on native forests, is one of the main benefits of eucalyptus stands. If native forests could be used sustainably, they would not be sufficient to meet the growing demand for forest products such as pulp, paper, sawmill, by-product industries, and biomass for bioenergy and biofuels (Viera et al., 2012).

Several tropical countries have the potential to greatly increase the productivity of managed forests above current levels (Toit et al., 2010). The challenge for silviculture is using management systems to achieve high growth rates and wood quality (Gonçalves et al., 2004), in addition to adopting environmentally sound practices for sustainable forest production (Chaer and Tótola, 2007). Strategies to achieve this goal include using genetically-improved trees, and implementing best harvesting and forestry practices; for example, by minimizing negative impacts from mechanized operations and ensuring adequate soil tillage, management and fertilization (Toit et al., 2010).

Among factors most influencing forest productivity, soil physical environment is very important and can be harmful or beneficial to trees (Cavalli et al., 2020), where the sustainability of forestry is directly related to soil conservation (Chaer and Tótola, 2007). Since the first Eucalyptus plantation establishment, this genus has been the subject of questions regarding its effect on soil quality (Rosa et al., 2018).

Soil quality in areas designed for forestry is affected by soil compaction from natural densification and or anthropogenic (traffic-induced) effects (Barros, 2001; Reichert et al., 2007, 2010, 2018a; Sampietro et al., 2015). Mechanization has been responsible for soil deterioration not only in agriculture, but also in forest areas, by the increased use of larger, heavier machines and increased vehicular traffic in conditions of inadequate soil moisture (Suzuki et al., 2014; Andrade et al., 2017). The most significant impact on soil physical properties under forests occurs in association with harvesting (felling, dragging and stocking) (Dedecek and Gava, 2005; Reichert et al., 2018a) and subsequent soil tillage for regrowth or new planting (Dedecek and Gava, 2005; França et al., 2021; Reichert et al., 2021a,b). These activities change soil structure and physico-hydraulic properties, hindering root growth, nutrient transport and consequently forest development (Dedecek and Gava, 2005; Silva et al., 2018; Reichert et al., 2021b).

Soil tillage is the most common and important management practice in silviculture, allowing for optimal resource management and lower environmental impact (Barrios et al., 2015). When used rationally, tillage can maintain or increase forest productivity in the medium- and long-term, reduce the degree of soil compaction and erosion by water and wind, and improve the cost/benefit ratio of available resources, including labor, machinery, and equipment and fuel (Gonçalves et al., 2000; Dedecek et al., 2007; Prevedello et al., 2014; Sampietro et al., 2015). Less soil tillage intensity for distinct tillage methods decreased the development of some dendrometric variables for eucalyptus, but possibly there is an optimal relationship between tillage method and initial tree growth (Lima et al., 2019) that must be further studied.

Although more intensive tillage might be necessary (Gatto et al., 2003; Prevedello et al., 2014; França et al., 2021; Reichert et al., 2021b), there are conditions in which less intensive tillage techniques are necessary. For example, in areas where several rotations have been conducted, the presence of stumps from harvested trees restricts or prevents the traffic of machines and equipment required for plantation management.

Understanding the behavior of the soil under different tillage methods in afforestation areas is essential for improving soil properties and functioning, and thus allowing for 
adequate forest growth without compromising soil conservation (França et al., 2021). Therefore, to assess soil physical quality, suitable indicators must be analyzed for their sensitivity to changes and disturbances caused by management activities, such as by tillage (Reichert et al., 2021a). Once defined, these indicators can be monitored to assess the impact of the adopted management practices on the soil quality in the medium- and long-term (Chaer and Tótola, 2007).

The United Nations sustainable development goals emphasize the importance of the soils in the earth system to achieve sustainability and accomplish the land degradation neutrality challenge (Novara et al., 2021). In this paper, we summarize relationships of soil type and properties, forest rotation, eucalyptus growth and productivity, and present research opportunities to increase the environmental and economic sustainability of forest plantations.

\section{DEVELOPMENT}

\section{Types of soil tillage and equipment used in forest areas}

Until the end of the 1970s, silvicultural practices related to soil management followed a typical agronomic pattern, including the burning of harvest residues and intense soil tillage by inversion. This was the only recommendation for large forest plantations, regardless of climate, soil type and forest genotype (Gonçalves et al., 2013). Over time, there have been changes to reduce tillage intensity for several reasons, including costs, legal environmental compliances and operational difficulties in reforming the plantations in areas with large stumps of previous forests (Barros and Comerford, 2002). Soil classification and soil texture of referenced studies in this review are presented in table 1.

Intensive cultivation and reduced soil tillage are tillage methods commonly used nowadays for planting exotic species. Intensive cultivation involves tilling of the soil surface layer, with total or partial incorporation forest residues. In this tillage type, disk plow, reformer plow, heavy and light harrow, and bedding harrow, among others, are commonly used equipment (Gonçalves et al., 2000). More intensive tillage has been necessary in areas of old pastures and in areas of reforestation of stands where wood exploitation and removal was done mechanically in the rainy season. In such situations, there is soil compaction in the trails caused by forest machines used for tree felling, dragging and stocking, thus reducing the growth of new seedlings and regeneration of sprouts (Barros and Comerford, 2002).

Reduced soil tillage has been widely examined as a solution for soil degradation (Cerdà et al., 2020). This tillage system involves the maintenance of forest residues on the soil surface, followed by localized tillage in the rows or planting pits. Reduced soil tillage has several technical, economic and ecological advantages, such as maintenance of soil physical quality, reduction in soil erosion, greater conservation of soil moisture and reduction in weed infestation (Gonçalves et al., 2007; Gonçalves, 2009; França et al., 2021; Reichert et al., 2021b,c). Subsoilers, chisels and drillers are the main equipment used in this type of tillage (Gonçalves et al., 2000). In countries in the southern hemisphere, subsoilers and pitting machines are more common during mechanized soil tillage (Ramantswana et al., 2020), whereas, in areas with a slope above 30-35\% (depending on terrain irregularity), soil tillage might be restricted to the manual opening of pits (Gonçalves, 2009).

Therefore, the best tillage method depends on soil type, level of compaction and slope (Gonçalves, 2009; Hakamada et al., 2013; Reichert et al., 2021a,b,c), and the local availability of equipment. Thus, we should not generalize the effects of soil tillage without understanding the soil properties and genotypes at different stages of forest growth and development (Reichert et al., 2021a,b). 
Table 1. Soil classification and soil texture of referenced studies

\begin{tabular}{|c|c|c|c|c|}
\hline \multicolumn{3}{|c|}{ Classification } & \multirow{2}{*}{ Textural class } & \multirow{2}{*}{ Reference } \\
\hline WRB-FAO ${ }^{(1)}$ & Soil Taxonomy ${ }^{(2)}$ & Brazilian system $^{(3)}$ & & \\
\hline Acrisol & Ultisol & Argissolo & $\begin{array}{l}\text { Sandy clay } \\
\text { loam to clay }\end{array}$ & $\begin{array}{l}\text { Cavalli et al. } \\
(2020)\end{array}$ \\
\hline-- & Mollic Hapludalf & Argissolo & Sandy & $\begin{array}{l}\text { Pérez Bidegain et al. } \\
\text { (2012) }\end{array}$ \\
\hline--- & Typic Hapludalf & $\begin{array}{c}\text { Argissolo } \\
\text { Vermelho-Amarelo } \\
\text { Distrófico arênico }\end{array}$ & Sandy loam & $\begin{array}{l}\text { Prevedello et al. } \\
(2013,2014)\end{array}$ \\
\hline Cambisol & Inceptisol & $\begin{array}{l}\text { Cambissolo } \\
\text { Úmbrico }\end{array}$ & Sandy loam & $\begin{array}{l}\text { Madeira et al. } \\
\text { (1989) }\end{array}$ \\
\hline Cambisol & Inceptisol & Cambissolo Háplico & $\begin{array}{l}\text { Medium with } \\
\text { gravel / clay }\end{array}$ & $\begin{array}{l}\text { Baptista and } \\
\text { Levian (2010) }\end{array}$ \\
\hline Cambisol & Inceptisol & $\begin{array}{c}\text { Cambissolo } \\
\text { Distrófico / Eutrófico }\end{array}$ & $\begin{array}{l}\text { Sandy loam to } \\
\text { loam texture }\end{array}$ & $\begin{array}{l}\text { Carneiro et al. } \\
\text { (2014) }\end{array}$ \\
\hline Arenosol & Quartzipsamment & $\begin{array}{c}\text { Neossolo } \\
\text { Quartzarênico típico }\end{array}$ & NP & $\begin{array}{c}\text { Hakamada et al. } \\
\text { (2013) }\end{array}$ \\
\hline $\begin{array}{l}\text { Dystric Rhodic } \\
\text { Hypersideralic } \\
\text { Nitisol }\end{array}$ & Inceptic Haplustox & $\begin{array}{l}\text { Nitossolo Vermelho } \\
\text { Distrófico típico }\end{array}$ & Clay & $\begin{array}{l}\text { Reichert et al. } \\
(2021 a, b)\end{array}$ \\
\hline Ferralsol & Oxisol & $\begin{array}{l}\text { Latossolo } \\
\text { Vermelho-Amarelo }\end{array}$ & NP & $\begin{array}{l}\text { Suiter Filho et al. } \\
\qquad(1980)\end{array}$ \\
\hline Ferralsol & Oxisol & Latossolo Vermelho & Clay & $\begin{array}{l}\text { Cavichiollo et al. } \\
\qquad(2003)\end{array}$ \\
\hline Ferralsol & Oxisol & $\begin{array}{c}\text { Latossolo Vermelho } \\
\text { Distrófico }\end{array}$ & Clay & Gatto et al. (2003) \\
\hline Ferralsol & Oxisol & $\begin{array}{c}\text { Latossolo Vermelho } \\
\text { Distrófico típico }\end{array}$ & Clay & $\begin{array}{l}\text { Hakamada et al. } \\
\qquad(2013)\end{array}$ \\
\hline Ferralsol & Oxisol & $\begin{array}{c}\text { Latossolo } \\
\text { Vermelho-Amarelo }\end{array}$ & Medium & Paes et al. (2013) \\
\hline $\begin{array}{l}\text { Orthoeutric } \\
\text { Lixic } \\
\text { Relictigleyic } \\
\text { Histic Planosol }\end{array}$ & Typic Endoaqualfs & $\begin{array}{l}\text { Planossolo } \\
\text { Háplico Eutrófico } \\
\text { gleissólico }\end{array}$ & Loam & $\begin{array}{l}\text { Reichert et al. } \\
(2021 a, b)\end{array}$ \\
\hline $\begin{array}{l}\text { Hypereutric } \\
\text { Regosol }\end{array}$ & $\begin{array}{c}\text { Typic } \\
\text { Ustipsamments }\end{array}$ & $\begin{array}{l}\text { Regosol } \\
\text { Eutroúmbrico típico }\end{array}$ & Sandy loam & $\begin{array}{l}\text { Reichert et al. } \\
(2021 a, b)\end{array}$ \\
\hline Acrisol & Ultisol & $\begin{array}{l}\text { Argissolo Bruno } \\
\text { Acinzentado }\end{array}$ & Medium & Finger et al. (1996) \\
\hline Acrisol & Kanhapludults & $\begin{array}{c}\text { Argissolo } \\
\text { Vermelho-Amarelo } \\
\text { Distrófico }\end{array}$ & $\begin{array}{l}\text { Medium / } \\
\text { clayey }\end{array}$ & $\begin{array}{l}\text { Wichert et al. } \\
\qquad(2018)\end{array}$ \\
\hline Acrisol & Ultisol & $\begin{array}{c}\text { Argissolo } \\
\text { Vermelho-Amarelo }\end{array}$ & $\begin{array}{l}\text { Sandy clay } \\
\text { loam to clay, } \\
\text { with high } \\
\text { gravel content }\end{array}$ & França et al. (2021) \\
\hline
\end{tabular}

${ }^{(1)}$ IUSS (2015). ${ }^{(2)}$ Soil Survey Staff (1999). ${ }^{(3)}$ Santos et al. (2013). NP: soil classification not presented in the study.

Plowing ruptures soil by turning over the surface layers, causing soil inversion. The most common types of plows are moldboard plows and disk plows, which differ in design and morphology. Sometimes, plowing and harrowing are done simultaneously. The working depth depends on the weight, and diameter and angle of the disks. Plows have great operational capacity and are used for the incorporation of organic residues after harvesting and crushing, and in incorporating weeds before plowing and preparing newly deforested soils (Ribeiro, 2005). 
Chisel plow and subsoiler are among the most used equipment for the establishment and recovery of forest plantations, as they carry out operations that improve the survival and growth of seedlings, by enabling roots to reach greater depths. Tillage depth is usually low $(0.30-0.50 \mathrm{~m})$, soil rupture is subsurface (Ribeiro, 2005), and no soil overturning is done, reducing the risk of soil erosion (Dedecek et al., 2007; Baptista and Levien, 2010).

Subsoiling has been regularly used in forest plantations because of its beneficial effects on the soil and its operational and economic advantages (Sasaki and Gonçalves, 2005). Subsoiling is a method of sufficient intensity to alleviate compaction in clayey soils, with no need for major turnover interventions, which has made it a standard operation used by most forestry companies (Reichert et al., 2021b). Subsoiling generates a series of rupture stresses that are transmitted to layers in the subsoil, and does not generate compaction below the operating depth of the equipment when done in adequate soil moisture (Rosa et al., 2011). For eucalyptus stands, a minimum working depth of $0.50 \mathrm{~m}$ is recommended (Dalbem et al., 2008), but the subsoiling depth decreases with the increase in soil slope (Pena Pereira et al., 2012).

In rugged reliefs, the smallest soil disturbance makes mechanical pit-drilling an adequate alternative to subsoiling (Baptista and Levien, 2010; França et al., 2021). However, technical and economic knowledge about alternative soil tillage methods for planting eucalyptus with pit-drilling is still incipient (França et al., 2021). Mechanical drilling lowers the total cost of silvicultural operations when compared with subsoiling. However, drilling provides the lowest initial growth of eucalyptus plants and can result in lower productivity of forest plantations in the reform area (França et al., 2021).

Tilling by rotary hoes causes soil fragmentation into aggregates of varying sizes (Ribeiro, 2005). Rototilling can be a complementary practice, such as used by Reichert et al. (2021b) in ridge tillage. In their study, a moldboard plow cut the soil to a depth of approximately $0.40 \mathrm{~m}$, and was responsible for soil movement to form the ridge $(0.80-\mathrm{m}$ wide, and 0.40-m high but shortening with time due to soil consolidation), while the rotary hoe performed the surface leveling, as a ridge-finishing operation.

Therefore, soil tillage activity varies depending on tillage purpose and soil characteristics, climate, weeds and harvesting residues. Before any intervention in the field, conducting an exploratory survey of the soil structural conditions is necessary (Reichert et al., 2021a), along with evaluating the species and genetic material to be planted (Morales, 2014). The effect of soil tillage depends not only on the equipment used, but also on the form and intensity of use. Often, the beneficial effect of a particular equipment is canceled out by its inappropriate or excessive use (Gonçalves et al., 2000).

\section{Effects of soil tillage on eucalyptus productivity}

Selected results for eucalyptus growth (seedling survival and tree circumference at breast height, height and volume) in different tillage and soil type, in first and second planting rotation, are shown in table 2 . Soil tillage, in addition to directly influencing the soil conservation potential (Sasaki and Gonçalves, 2005), is a prime factor influencing the initial growth of eucalyptus, and consequently for the uniformity and production of the forest (Suiter Filho et al., 1980; Sasaki and Gonçalves, 2005; Padilha et al., 2018; França et al., 2021; Reichert et al., 2021b).

Soil tillage constitutes a strategy for improving soil quality to meet, sustainably, the requirements of plants and other beings (Barros, 2001), which consequently generates conditions for improved productivity (Cavichiolo et al., 2003). However, if used improperly, tillage techniques can physically, chemically and biologically degrade the soil in a few years of use, reducing its productivity potential (Gonçalves et al., 2000). Since soil tillage changes physical, hydraulic and mechanical properties of the soil and, consequently, crop development and productivity (Klein et al., 2009; Fasinmirin and Reichert, 2011; 
Table 2. Eucalyptus spp growth (seedling survival, and tree diameter at breast height DBH, height, and volume) in different soils and tillage type and depth, in first and second planting rotations

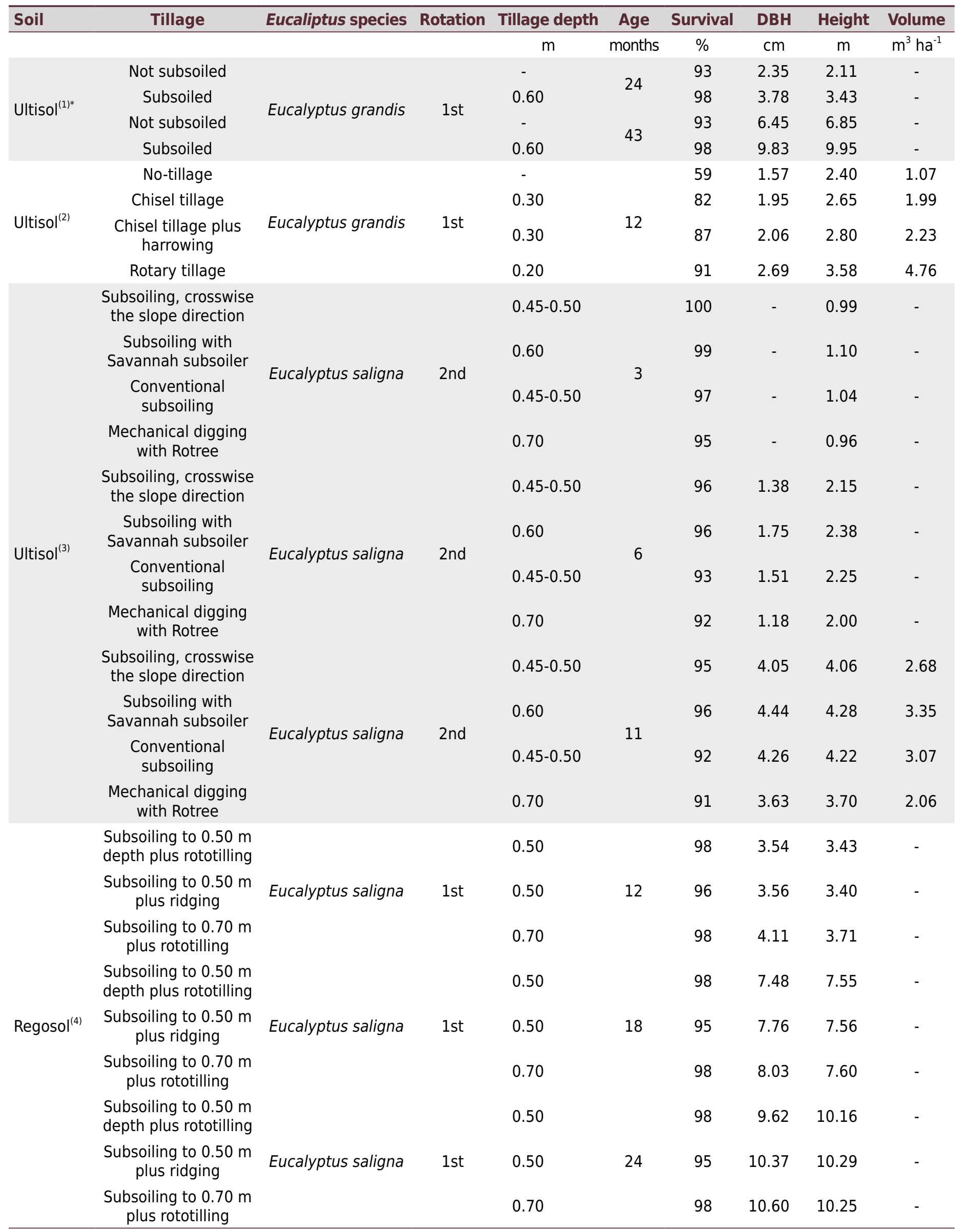


Continuation

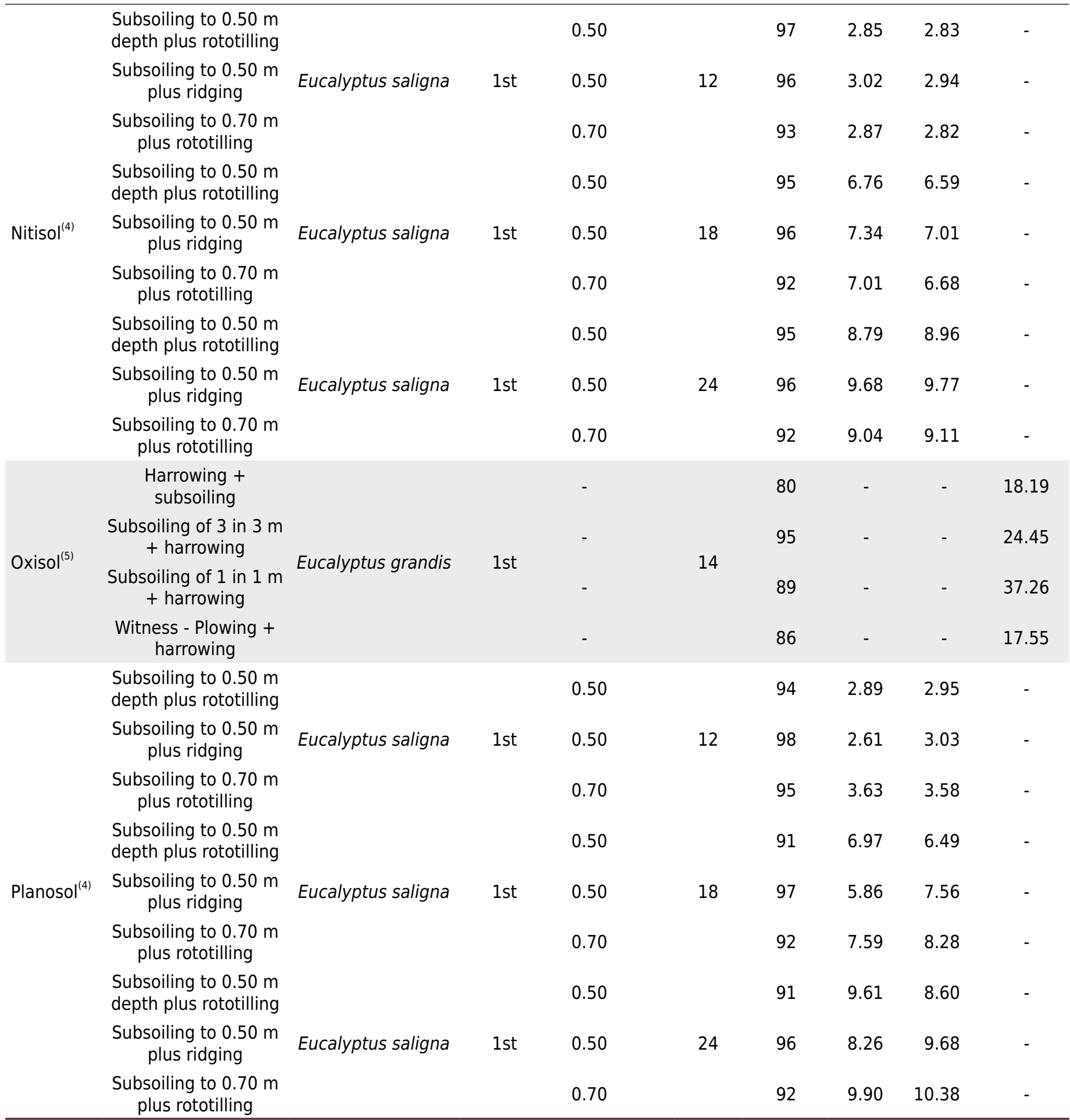

${ }^{*(1)}$ Finger et al. (1996). ${ }^{(2)}$ Prevedello et al. (2013). ${ }^{(3)}$ França (2017). ${ }^{(4)}$ Morales et al. (2014). ${ }^{(5)}$ Suiter Filho et al. (1980).

Reichert et al., 2019, 2020a; Awe et al., 2020), soil physical environment is decisive for the initial growth of eucalyptus (França et al., 2021; Reichert et al., 2021b). Initial development is defined as the period between planting and the closing of the canopy, which occurs between the ages of one and two years for plantations with a spacing of 6 to $9 \mathrm{~m}^{2}$ (Stape et al., 2002).

Although in the forestry sector, minimum tillage outstands towards increased forest productivity and soil biodiversity and conservation (Prevedello et al., 2013), several studies have indicated a positive relationship between the volume of ruptured soil 
and the initial development of eucalyptus (Suiter Filho et al., 1980; Finger et al., 1996; Cavichiolo et al., 2003; Gatto et al., 2003; Baptista and Levien, 2010; Prevedello et al., 2013; Wichert et al., 2018; Reichert et al., 2021b).

Root growth, and crop development and production are influenced by the level of soil compaction, which depends on management system (Prevedello et al., 2013). With soil compaction, the absorption of water and nutrients is reduced because roots are impeded from accessing a larger volume of soil (Silva et al., 2018). Therefore, forest productivity can be temporarily or permanently impaired in compacted soils (Silva et al., 2018). Visual inspection in studies by Prevedello et al. (2013) and Reichert et al. (2021b) showed eucalyptus roots occupied mainly the soil ruptured by soil tillage.

Initial growth of forest stands established under minimum tillage is generally slower and more heterogeneous due to soil biological activity and mineralization rate of crop residues. Burning or incorporation of residues in the soil accelerates residue mineralization by combustion or biological activity, respectively, providing greater amounts of nutrients for seedlings. By contrast, when the residues are left on the ground, their decomposition is gradual, where microorganisms can compete for nutrients with the seedlings through the immobilization of nutrients (Gonçalves et al., 2000).

Sometimes minimum tillage can be adopted, but in others, a more intensive tillage intervention will be necessary for greater plant survival and growth. Factors such as previous use amount of harvest residues from previous crop; presence, distribution, and size of stumps; physical soil conditions; topography of the area; and climate must be considered when deciding on tillage techniques (Barros and Comerford, 2002).

When assessing the influence of soil compaction on the productivity of eucalyptus regrowth, timber volume is affected by the soil compaction caused by machine traffic during harvest, reaching reductions of up to two-thirds with a high degree of compaction (Dedecek and Gava, 2005). As a result, soils with high natural bulk density or caused by mechanization or trampling require some tillage practice (Barros and Comerford, 2002). Thus, pedological knowledge of the soil and monitoring of the level of compaction before tillage is essential to achieve the productive potential of the site (Hakamada et al., 2013), given that the effects of soil tillage on forest growth are highly dependent on the type of soil granulometry, depth and drainage (Reichert et al., 2021b).

\section{Tillage and productivity in soils under undulated relief, with a focus on Ultisols and Alfisols}

Eucalyptus silviculture is expanding to high slope areas formerly occupied by degraded pastures, because of limited agricultural value of these lands and their greater aptitude to support forests (Wichert et al., 2018). The establishment and growth of eucalyptus are favored by soil tilling, which can increase the productivity of forest stands (Prevedello et al., 2013). On the other hand, Pérez Bidegain et al. (2012) found no-tillage system did not affect Eucalyptus grandis productivity in the first rotation in a mollic Hapludalf, and it was impossible to obtain adequate timber production with the use of reduced tillage.

Ultisols are soils of variable depth, strong to imperfectly drained, reddish or yellowish colors, and more rarely, brownish or grayish, the texture varying from sandy to clayey in the A horizon and from medium to very clayey in the Bt horizon. In this type of soil, Finger et al. (1996) evaluated the effect of subsoiling and non-subsoiling on the survival and increase in growth of Eucalyptus grandis in the first rotation. A positive difference was observed in all measured variables favoring seedlings planted in subsoiled areas (Table 2). In the same region, Prevedello et al. (2013) evaluated the initial development of Eucalyptus grandis in different types of soil tillage in a Typic Hapludalf, also in the first rotation. They observed that survival, growth, and basal area and volume increased as 
soil tillage was intensified (Table 2). The authors found that eucalyptus seedlings showed greater growth in diameter and height in rotary-tilled soil, while the lowest growth was obtained in untilled (fallow) soil. Low growth in fallow soil may be associated with greater difficulty in establishing roots in the initial period of plant development due to the absence of soil rupture and greater competition by weeds. Weed interference in eucalyptus stands is mainly due to competition for resources in the environment, and this competition is more expressive in first year of crop growth (Santos et al., 2005).

Initial development of Eucalyptus grandis in an Ultisol in the first rotation was increased by mechanical pit-drilling and residue maintenance on site (Wichert et al., 2018). Removal or maintenance of crop residues in eucalyptus plantations influences soil quality and productivity (Carneiro et al., 2014). Residues and organic materials, in addition to partially dissipating applied loads and reducing soil compaction (Braida et al., 2006, 2007a,b, 2008, 2010; Reichert et al., 2007, 2014, 2015, 2016a,b; Holthusen et al., 2018a,b), increase soil organic matter content, functioning as a source of slow release of nutrients to the ecosystem (Wichert et al., 2018), where tillage itself affects the carbon balance (Weiler et al., 2019).

Restoration of trees in forest plantations after harvesting requires soil structure to be improved as heavy machineries used for harvesting usually cause soil compaction and deformation, mainly on the surface but also in deeper layers. França et al. (2021) evaluated the effects of four different soil tillage methods on the initial growth of eucalyptus in a second rotation, in an Ultisol. They observed the most intensive and expensive method (cross-slope subsoiling after stump cutting plus ridging, with stump) provided the best conditions for tree growth, while pit-drilling with Rotree equipment was the least efficient due to low-cost productivity. Therefore, the best tillage will depend on soil type and compaction, history of land use and land slope.

\section{Tillage and productivity in poorly-developed (Cambisols and Regosols) and poorly-drained soils (Planosols)}

Cambisols have great variation in relation to depth, including shallow to deep profiles, with drainage varying from accentuated to imperfect, and are often stony, gravelly, or rocky. In this type of soil, Carneiro et al. (2014) evaluated the effects of waste management and tillage systems on the growth of Eucalyptus globulus plantations in the first rotation. They observed the maintenance of crop and litter residues followed by deep soil disturbance directed to greater timber production. Moreover, incorporating residues into the soil followed by ripping (subsoiling) is probably the best option for combining production and environmental sustainability of eucalyptus plantations. On the other hand, in second rotation stands of Eucalyptus saligna, Baptista and Levien (2010) observed total biomass of eucalyptus seedlings planted in plots with continuous subsoiling without residue was $80 \%$ greater than that of the treatment with mechanical pit-drilling. Soils subjected to tillage without residue provided a greater volume of ruptured soil, creating physical conditions favorable for adequate root development. Therefore, the more intensive soil tillage contributed to the higher initial growth of eucalyptus, but increased soil erosion.

Regosols are less developed, usually shallow soils, consisting of mineral material or organic material. In this type of soil, Reichert et al. (2021b) evaluated initial growth parameters of Eucalyptus saligna clones (first rotation) in three tillage methods: subsoiling to $0.50 \mathrm{~m}$ depth plus rototilling $(\mathrm{S} 50+\mathrm{Ro})$, subsoiling to $0.50 \mathrm{~m}$ plus ridging (S50+Ri), and subsoiling to $0.70 \mathrm{~m}$ plus rototilling $(\mathrm{S} 70+\mathrm{Ro})$. The authors observed that the best practice of soil tillage when considering the height of the trees was S50+Ri and, when considering the diameter, it was S50+Ro. They also observed that the trees planted after the $\mathrm{S50+Ro}$ tillage had less weed competition. Therefore, subsoiling plus ridges is an important method of tillage in shallow soils. 
In an area previously occupied by eucalyptus, Hakamada et al. (2013) evaluated Eucalyptus grandis $\times$ Eucalyptus urophylla at 72 months of age, under different types of tillage in a sandy Regosol. The authors found a reduction in survival by $15 \%$ in the tillage with pit-drilling (pitting), and $9 \%$ in tillage with harrowing when compared to subsoiling. Furthermore, timber productivity in the area prepared with pitting was $16 \%$ lower than that obtained with subsoiling. Disk harrowing did not show any difference in productivity compared with subsoiling. These results show that even in sandy soil with low susceptibility to compaction, subsoiling should be carried out depending on the intensity of machine use and traffic in previous rotations.

Planosols comprise mineral soils, imperfectly or poorly drained, with a subsurface horizon with high clay content. These soils present imperfect drainage in periods of greater rainfall, which can consequently cause oxygen deficiency, affecting the development of eucalyptus (Morales, 2014). Thus, in hydromorphic soils, soil tillage and furrows contribute to improving soil drainage and aeration.

Although there is a vast literature on the tillage and use of Planosols for annual crops (Goulart et al., 2020, 2021), there is practically no information for forestry despite its use for eucalyptus cultivation. In this type of soil, Reichert et al. (2021b) evaluated the initial growth parameters of Eucalyptus saligna clones in the first rotation, and found that the best practice of soil tillage, when considering tree height, was subsoiling to $0.50 \mathrm{~m}$ plus ridging and, when considering tree diameter, the best tillage option was subsoiling to $0.50 \mathrm{~m}$ depth plus rototilling. Therefore, subsoiling plus ridging is an important tillage method in poorly drained soils.

\section{Tillage and productivity in well-drained soils in flat to smooth-wavy relief, with a focus on Nitisols and Oxisols}

Nitisols are soils with a clayey or very clayey texture with an expressive textural difference. In this type of soil, Reichert et al. (2021b) observed that for the initial growth of Eucalyptus saligna clones in first rotation, when considering tree height and diameter, the best soil tillage practice was subsoiling to $0.70 \mathrm{~m}$ plus rototilling $\left(\mathrm{S}_{70}+\mathrm{Ro}\right)$. Tree height in this tillage method was $8 \%$ greater than subsoiling to $0.50 \mathrm{~m}$ depth plus rototilling $\left(\mathrm{S}_{50}+\mathrm{Ro}\right)$. Tree diameter and basal area were greater for $\mathrm{S}_{70}+$ Ro than for $\mathrm{S}_{50}+$ Ro by 20 and $15 \%$, respectively. Therefore, deep subsoiling is an important tillage method in clayey soils (Reichert et al., 2021b).

Oxisols are highly weathered, deep and well-drained soils. In this soil type, Suiter Filho et al. (1980) studied several soil tillage methods to evaluate the development of Eucalyptus grandis in first rotation at 14 months of age, in Minas Gerais. The authors observed that the average volume obtained for subsoiling at every $1 \mathrm{~m}$ plus harrowing with bedding was $112 \%$ greater than the volume obtained with plowing and harrowing. The highest seedling survival was observed for subsoiling at every $3 \mathrm{~m}$ plus harrowing with bedding, which presented a value of $6.2 \%$ greater than the subsoiling at every $1 \mathrm{~m}$ plus harrowing with bedding (Table 2). Therefore, subsoiling is a practice that contributes to eucalyptus development in clayey soils.

Soil tillage is often used after harvesting operations, with the purpose of improving soil physical conditions for seedling survival (Cavichiolo et al., 2004). The soil conditions determined by tillage practices influence the mortality and growth of forest species (Fonseca et al., 2011; França et al., 2021), as observed by Cavichiolo et al. (2004) when studying the effect of different tillage systems on the productivity of Eucalyptus saligna regrowth (second rotation) in a clayey Oxisol. The authors found that treatments with soil tillage showed higher growth. Further, Gatto et al. (2003) studied the effects of different soil tillage methods on the productivity of Eucalyptus grandis stands in third rotation, in a dystrophic Oxisol, in Minas Gerais. As soil tillage was intensified, a trend of increasing tree survival, circumference, and height was observed, which was reflected 
in greater volume. These authors attributed the greater growth to the intensity of soil tillage to improve conditions for nutrients and water absorption by eucalyptus plants, and to the reduction of weed competition.

Effect of harrowing and furrowing was assessed by Cavichiolo et al. (2003) in the productivity of Eucalyptus saligna regrowth (second rotation) at one year of age in Oxisols with different granulometry (clayey texture), and at two years of age (medium texture). Harrowing and subsoiling effects were more evident in clayey soil. Increase in tree height was markedly different for the treatments with soil tillage compared to the control, where subsoiling showed the highest average values. Thus, tilling to greater depth reduces mechanical resistance, which favored the increase in tree height, and possibly the furrow used in tillage produced satisfactory results. Further, the increment in tree diameter with soil tillage was higher than in control. The maximum increments in height and diameter of regrowth were observed in both years in soil tillage with furrower. However, the increase in tree diameter showed a significant difference between treatments and was greatest after harrowing.

In an area previously occupied by Eucalyptus, Hakamada et al. (2013) evaluated the productivity of Eucalyptus grandis $\times$ Eucalyptus urophylla at 72 months of age under subsoiling, manual pitting, and disk harrowing, in an Oxisol. They found timber productivity in the area with pit-drilling was $17 \%$ lower than that in the subsoiled area. There was no significant difference in seedling survival. From these results, it can be concluded that subsoiling is valid as an adequate tillage method for clayey soils, not requiring a more intensive method, which would result in a greater risk of erosion and higher costs when compared to subsoiling.

In the second rotation of an 83-month-old Eucalyptus grandis $\times$ Eucalyptus urophylla plantation, Paes et al. (2013) found no difference in the volume of timber comparing tillage with a one-shaft and a three-shaft subsoiler. However, the maintenance of forest residues in the area resulted in an increase of $36.6 \%\left(71.7 \mathrm{~m}^{3} \mathrm{ha}^{-1}\right)$ in timber volume compared with removing all residues after harvest.

\section{Soil physical properties in different types of tillage}

The process of mechanization in the forestry sector has significantly increased productivity, reduced costs, and improved the quality of forestry operations. However, excessive use of machinery, intensive cultivation, and inadequate soil management are responsible for considerable environmental impacts, especially soil compaction. Compacted soil has reduced plant growth, leading to lower levels of organic matter in the soil, reduction in nutrient cycling and mineralization, and the activities of microorganisms, in addition to increasing wear and tear of cultivation machinery (Hamza and Anderson, 2005; Sampietro et al., 2015; Silva et al., 2018).

Soil compaction occurs in a wide range of soil types and climates, and is aggravated by low organic matter content (Braida et al., 2007a, 2010; Reichert et al., 2018b) and tillage in inadequate soil moisture (Silva et al., 2002; Hamza and Anderson, 2005; Veiga et al., 2007; Reichert et al., 2018b). The compaction process results from stresses applied to the soil during silvicultural activities (weed control, soil tillage and fertilization), and tree felling, and timber dragging and stocking. With compaction, there is an increase in bulk density and mechanical resistance to root growth, and a reduction in porous space, infiltration and internal drainage of water (Sampietro et al., 2015; Silva et al., 2018). In forest areas, the depth of compaction is generally greater than in agricultural or livestock areas, because the weight of machinery is greater, traffic during harvest is more intense, and there is a possibility of higher soil moisture due to the shading caused by the species in these forest plantations (Suzuki et al., 2012). 
Land use and management affect the degree of compaction to varying intensities (Suzuki et al., 2015). When the soil is subjected to external pressure, soil compressibility and shearing depends mainly on soil granulometry and moisture (Reichert et al., 2010, 2018b). Thus, performing traffic on soil conditions less prone to compaction, for example, by managing traffic based on soil moisture, can reduce the risk of compaction (Dias Junior et al., 2005; Richart et al., 2005; Milde et al., 2010; Reichert et al., 2014). Another strategy is restricting traffic to specified lanes and thereby limiting the area affected by soil compaction (Sampietro et al., 2015).

Avoiding compaction in an intensive production system is difficult when machines are getting larger, heavier, and more powerful (Reichert et al., 2007). However, compaction can be prevented if the soil's load-bearing capacity is not exceeded, which makes it important to assess both the mechanical strength of the soil and the impact of different operations (Andrade et al., 2017). However, each soil presents a unique behavior in relation to traffic. Considering soil diversity, area heterogeneity, and different management practices adopted by companies and foresters, each condition must be analyzed individually to make decisions regarding soil compaction (Reichert et al., 2007). Assessing soil quality is an important tool for identifying the most sustainable soil management practices (Fonseca and Figueiredo, 2016).

In forest areas, the response of plants to soil quality indicators is not very simple. Unlike annual crops, trees have a longer cycle, being subject to climatic variations and anthropic actions for several years (Suzuki et al., 2014). Eucalyptus productivity is significantly influenced by functional properties and soil composition, where water and air storage capacity and water permeability are the main soil properties related to the site's productivity potential (Cavalli et al., 2020). Therefore, plants need soils with proper physical conditions for flow of water, heat and gases. Soil moisture, in turn, controls aeration, temperature and mechanical resistance, which are affected by soil bulk density and pore-size distribution. These physical factors interact and regulate the growth and functionality of the roots, affecting productivity (Collares et al., 2006).

Soil physical properties commonly used as indicators to assess soil quality are based on direct and indirect factors of plant growth, such as bulk density, resistance to root penetration, availability of water in the soil and aeration (Cecagno et al., 2016; Reichert et al., 2016c). Among the properties used to assess soil compaction, bulk density is probably the safest, as it has less or no dependence on other factors such as moisture (Reichert et al., 2007). Bulk density values based on restrictions to growth and yield of annual crops or the optimal water range (Secco et al., 2009; Suzuki et al., 2013) have the potential to be used in perennial crops and pasture (Suzuki et al., 2012).

Soil resistance to penetration is one of the limiting factors to the development and establishment of crops, as it expresses the degree of soil compaction, and varies with the type of soil and with the cultivated species, and its causes have been attributed to machine traffic (Richart et al., 2005). Several studies have sought a value or a range of critical resistance values that restrict the growth of plants. However, there are still uncertainties regarding these values, as different plants respond differently to critical values. Although this assessment is more sensitive in identifying compacted soil layers, it does not consider soil bioporosity, which is an important factor affecting permeability (Abreu et al., 2004) and root growth in compacted soils (Reichert et al., 2007).

Soil bulk density and porosity are properties related to volume changes. Density has an inverse relationship with porosity. Generally, porosity reduction occurs with a reduction in larger pores, responsible for water infiltration and soil aeration, followed by an increase in the number of smaller pores (Reichert et al., 2007, 2014). Machine traffic and no-tillage can reduce the volume of larger pores and increase the smaller ones, while tillage can promote the opposite behavior (Reichert et al., 2017a). Therefore, 
because of the importance of soil physical properties, especially from the second rotation onwards, tillage operations play an important role in forest productivity (Cavichiolo et al., 2003).

\section{Tillage and physical properties in soils under wavy relief, with a focus on Ultisols and Alfisols}

The choice of best soil tillage depends on the granulometry, degree of compaction, critical density and resistance of the soil to penetration (Morales, 2014). Evaluating the effect of soil tillage methods in a first rotation Eucalyptus grandis plantation, cultivated in a Typic Hapludalf with a sandy-loam texture, Prevedello et al. (2013) observed that soil managed under no-tillage presented the highest values of bulk density and resistance to penetration, which resulted in restrictions to plant root and shoot growth. In contrast, chisel tillage, chisel tillage plus harrowing, and rotary tillage reduced the resistance to penetration and density to a depth of $0.30 \mathrm{~m}$.

Soil tillage significantly impacts soil structure (Dedecek et al., 2007; Reichert et al., 2014; França et al., 2021; Reichert et al., 2021a). In a study by Prevedello et al. (2014), soil tillage with chiseling, chiseling followed by harrowing, and with a rotary resulted in less structural stability of aggregates, with a reduction in the percentage of aggregates in the larger diameter class. The highest aggregation index was found in soils that were not tilled (Prevedello et al., 2014). Thus, the role of organic constituents in the formation and stabilization of aggregates is fundamental (Wohlenberg et al., 2004; Braida et al., 2007a, 2011; Batistão et al., 2020; Holthusen et al., 2020; Alves et al., 2021; Awe et al., 2021), especially in conservation forestry (Prevedello et al., 2014), in which the accumulation of crop residues on soil surface and less soil mobilization contributes to the formation and stabilization of aggregates (Silva et al., 2006).

Aggregate size and stability strongly influence air and water flow in the soil (Suzuki et al., 2014). Considering the initial growth gains of eucalyptus in first rotation and erosive losses, Wichert et al. (2018) found that the maintenance of residues on site and mechanical pit-drilling as best management options for these areas, with a tendency for greater soil loss with increasing soil tillage intensity.

Areas cultivated for the second or more rotations may have compacted soil structure from the surface to deeper layers, owing to machine traffic during the harvesting operations of the previous crop (França et al., 2021). In an area planted with eucalyptus for commercial purposes, compaction negatively affects the soil structure down to the $0.40 \mathrm{~m}$ layer (Suzuki et al., 2014). When the soil is compacted, its resistance is increased and the total porosity is reduced at the expense of larger pores. As a result, volumetric water content and field capacity are increased, while aeration, water infiltration rate and hydraulic conductivity of saturated soil are reduced. Consequently, surface runoff may increase and plant growth may be reduced due to decreased water availability, restricted root growth, and poor aeration (Reichert et al., 2007).

High productivity of eucalyptus was directly related to high microporosity, low resistance to root penetration and adequate soil permeability (Cavalli et al., 2020). Therefore, efficient soil tillage techniques are required to reduce compaction and provide a physical environment suitable for eucalyptus growth and development, with the least environmental degradation and the lowest cost of operations (França et al., 2021). In a second rotation area, Madeira et al. (1989) compared the effects of minimal (surface disk harrowing) and intensive (deep plowing) soil tillage techniques in a 30-month-old Eucalyptus globulus stand. They observed that disk harrowing resulted in a significant decrease in soil bulk density down to $0.30 \mathrm{~m}$ depth and an increase in aeration porosity in the 0.00 to 0.10 $\mathrm{m}$ layer. Deep tillage decreased bulk density in depths from 0.10 to $0.80 \mathrm{~m}$, while water infiltration rate was highest with disk harrowing. 
Different tillage systems may improve soil conditions (Dedecek et al., 2007). For example, França et al. (2021) evaluated the effects of different soil tillage methods in a second rotation Eucalyptus saligna stand, and observed that all treatments resulted in a less dense topsoil, with increasing impact over time. As reasons for these changes, they considered that soil tillage (in the short term) and root growth (in the long term) changed soil structure. As confirmed by the study area characterization before the tillage experiment, high and/or repeated loads possibly increased bulk density, both in the soil surface and subsoil. The crop presumably was more affected in the short term (immediately after planting and in the measurement interval of 122 days after planting), and the effect of the roots dominated the results 391 days after planting. Therefore, mechanization in soil tillage must be accompanied by techniques that allow for the smallest possible further changes in soil physical properties, allowing for sustainability and preventing land degradation (Richart et al., 2005).

\section{Tillage and physical properties in poorly developed soils (Cambisols and Regosols) and poorly drained (Planosols)}

Evaluating three tillage methods in a first rotation Eucalyptus saligna stand implanted in Regosol, Reichert et al. (2021b) observed soil bulk density was lower in the layer $0.00-0.40 \mathrm{~m}$ for subsoiling to $0.50 \mathrm{~m}$ plus ridging. The highest macroporosity was found in the same type of tillage. However, pores formed by the roots are more stable due to the biological action, including the release of exudates and the presence of organisms that act in the decomposition of organic materials, leading to greater stability and durability of the pores compared to those formed by mechanical tools (Reichert et al., 2014).

Soil tillage can affect some processes of the hydrological cycle (Padilha et al., 2018). Seeking to identify and quantify the effect of soil tillage methods and crop residue management on water erosion in a Eucalyptus saligna forest (first rotation) in a Cambisol, Baptista and Levien (2010) observed that the soil loss due to the continuous subsoiling treatment without residue was ten times greater than that of the other subsoiling treatments and 100 times higher than that of mechanical pit-drilling. The greatest soil losses occurred shortly after soil tillage and before the canopy closed, thus demonstrating the importance of adequate tillage methods (Wichert et al., 2018). Soil tillage erosion can be controlled by reducing operations, regulating speed and depth, and choosing more sustainable tillage tools (Novara et al., 2019). Therefore, although subsoiling is almost a standard operation in commercial productions of eucalyptus, it is recommended mainly for deep, cohesive soils. For sloping terrains, which are prone to soil erosion, pit-drilling and interrupted subsoiling are options that increase soil and water conservation (França et al., 2021).

In a Planosol, different tillage methods in a first rotation Eucalyptus saligna were evaluated Reichert et al. (2021b), and observed bulk density in the 0.00-0.10 m layer was lower for subsoiling to $0.50 \mathrm{~m}$ plus ridging $\left(\mathrm{S}_{50}+\mathrm{Ri}\right)$. Macroporosity increased with tillage intensity. Greatest porosity was found in the $0.00-0.10 \mathrm{~m}$ layer with subsoiling to $0.50 \mathrm{~m}$ depth plus rototilling and subsoiling to $0.50 \mathrm{~m}$ plus ridging. Nonetheless, best tillage practices for soils with drainage and effective-depth constraints for subtropical forest plantations in South America are yet to be identified (Reichert et al., 2021b).

\section{Tillage and physical properties in well-drained soils under flat to wavy relief, with a focus on Nitisols and Oxisols}

In forest areas, where plants have a longer cycle than annual crops, it is important to propose and test indicators related to the environment, but with plant growth and development (Suzuki et al., 2014). In a stand of Eucalyptus saligna in first rotation implanted in a Nitisol, Reichert et al. (2021b) observed soil bulk density was lowest in the 0.00-0.10 $\mathrm{m}$ layer, for subsoiling to $0.50 \mathrm{~m}$ depth plus rototilling. In addition, subsoiling to $0.70 \mathrm{~m}$ plus rototilling $\left(\mathrm{S}_{70}+\mathrm{Ro}\right)$ was the tillage method with the lowest soil bulk density 
in the deepest layer evaluated $(0.40-0.60 \mathrm{~m})$. The highest total porosity was observed for subsoiling to $0.70 \mathrm{~m}$ plus rototilling and subsoiling to $0.50 \mathrm{~m}$ plus ridging. According to Sasaki and Gonçalves (2005), in addition to the operational aspect, plant physiology must also be considered, which implies subsoiling at adequate soil moisture for efficient tillage and proper establishment of plants.

Negative impacts on soil physical properties resulting from harvest, such as from compaction by traffic, are strongly related to soil granulometry (Toit et al., 2010). In a regrowth area of Eucalyptus saligna (second rotation), Cavichiolo et al. (2003) observed that the effects of harrowing and subsoiling were more evident in clayey soil. Significant differences were found in depth from 0.00 to $0.10 \mathrm{~m}$, where harrowing showed lower bulk density than the subsoiling. This was possibly because of greater traction force exerted by tractors used in this operation, and also because subsoiling generated less soil rupture. In the deeper soil layer, the control without soil tillage showed higher bulk density. Soil inversion to greater depths also reduced the resistance to penetration.

Several studies show total porosity increases with tillage (Cavichiolo et al., 2004; Dedecek et al., 2007; Morales, 2014). In an Oxisol with clay texture, in a one-year-old Eucalyptus saligna regrowth area, Cavichiolo et al. (2004) observed porosity was significantly higher with soil subsoiling at the greatest sampled depth. Aeration porosity was higher in the layer that was harrowed.

In eucalyptus plantations under reform management, additional soil disturbance arrives from mechanical tillage for the new planting. Such disturbances are related to soil compaction and disintegration, and the incorporation of organic residues and horizons into the soil mass of the tilled profile (Soares et al., 2019). In a third rotation Eucalyptus grandis plantation, Gatto et al. (2003) observed that the tillage systems adopted caused small changes in soil physical properties. Lower soil bulk density was found in areas where removal and subsoiling were carried out, as a consequence of soil rupture provided by tillage. On the other hand, soil bulk density was slightly greater in treatments with only burning and minimum tillage than in tilled areas. Tillage with chopping and burning of vegetation and subsequent manual removal of stumps and plowing improved all physical indicators, but only in the short term, namely less than a month (Reichert et al., 2014).

\section{Research opportunities}

Research opportunities include a better definition of tillage equipment for different soil conditions; evaluation of tillage effects on eucalyptus growth and productivity; the need of subsoiling between rows in established plantations; soil tillage in poorly-drained areas; tillage for highly-sandy soils, is there a need for subsoiling?; soil quality parameters for areas with ridging tillage; and pit-drilling vs. subsoiling, which is the most recommended for sloping areas in terms of productivity and soil erosion?; and generation of compaction risk maps and need for special soil tillage.

Furthermore, study approaches used for agricultural crops can be adapted or improved for eucalyptus. In particular, opportunities are related to tillage in compacted areas by forest harvesting, by previously defining different soil compaction states in the field, such as performed for agricultural crops (Secco et al., 2009), considering spatial variability in soil physical properties (Silva et al., 2003; Marins et al., 2018); short- and long-term tillage (Veiga et al., 2008, 2009, 2010; Reichert et al., 2016c) and cropping systems effects (Awe et al., 2015; Cecagno et al., 2016; Ambus et al., 2018; Reichert et al., 2022); refinement of plant available water as affected by soils and tillage, using existing pedotranfer functions (Vaz et al., 2005; Reichert et al., 2009, 2020b) or by developing improved ones, as well as via soil water balance (Reichert et al., 2021d), forest hydrology (Ferreto et al., 2021a) or catchment water-budget fluxes (Reichert et al., 2017b, 2021e; Ebling et al., 2021; Ferreto et al., 2021b; Valente et al., 2021). 


\section{FINAL REMARKS}

Mechanized soil tillage must consider soil type, particularly land slope, drainage and soil depth (Figure 1), along with forest rotation (first or higher-order). Soil surveys, including soil physical (e.g., compaction, granulometry including gravel) and morphological properties (e.g., horizons, solum depth, subsurface drainage impedance) are essential for foresters to make knowledgeable decisions on soil tillage, provided tillage is the single most costly practice in eucalyptus forestry.

Subsoiling plus ridging or bedding is required in low-drainage or shallow soils, whereas deep-subsoiling is essential in clay soils. The ridges can be built by grade bedding or terracing plows. In areas with waterlogging, ridging without subsoiling might be an option, but drainage is required.

Subsoiling, using parabolic shanks with a wing on subsoiler tip, is the most common soil tillage for eucalyptus, but it is best for deep, drained soils. On clayey cohesive soils, the necessary tillage depth might be of $0.70 \mathrm{~m}$ or more (deep) to ameliorate compacted soil of low microporosity and restriction to root growth, but $0.50-\mathrm{m}$ (shallow) subsoiling plus ridding produce similar results. Subsoiling plus ridging is required in low-drainage or shallow soils to increase the soil volume to be explored by roots. Chiseling performed for fertilizer application (minimum $0.25 \mathrm{~m}$ deep) might be the only tillage required for non-compacted sandy soils.

On sloppy lands downslope subsoiling increases the risk for soil erosion, which may be reduced by interrupted ripping, or mechanized hole- or pit-drilling. Manual or mechanical pit-drilling, with pits $0.30-\mathrm{m}$ deep or more, could also be an option for second or higher rotations, but results have shown that early growth is restricted, possibly because of root confinement. For second or higher rotations, stumps require cutting to allow crossslope tractor traffic and tillage.

Research opportunities include further studies for problem soils, such as slopy lands and low-drainage or compacted soils, tillage affecting soil erosion and eucalyptus productivity, equipment for special tillage, and mapping risk of compaction and special tillage needs, among others. Approaches used to study short- and long-term effects of tillage on soil properties and performance of agricultural crops could also be tested and improved for eucalyptus crop.

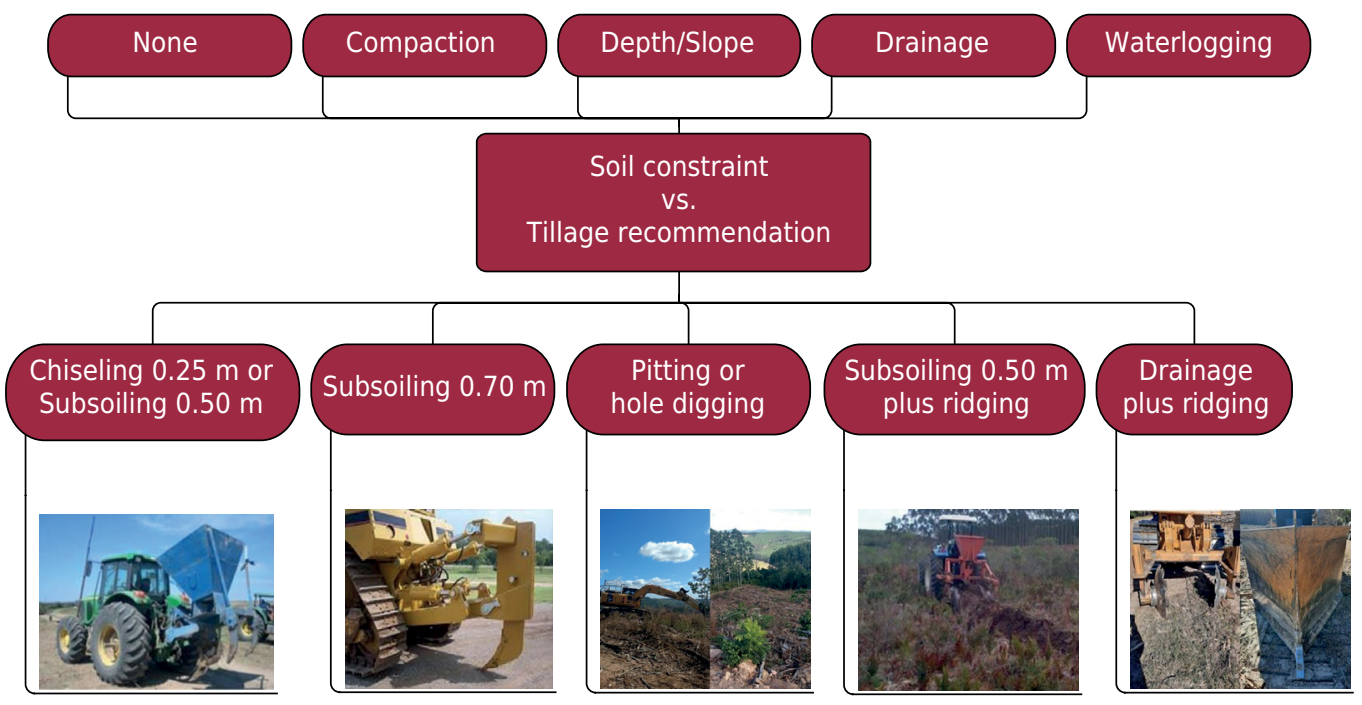

Figure 1. Soil tillage recommendation for soils with different physical constraints. Pictures taken by Elias Frank de Araújo. 


\section{ACKNOWLEDGMENTS}

We thank Capes (Coordination for the Improvement of Higher Education Personnel) Finance code 001, CNPq (National Council for Scientific and Technological Development), Fapergs (Fundação de Amparo à Pesquisa do Estado do Rio Grande do Sul), and CMPC Celulose Riograndese for partial fundings of studies of our research group; and Elias Frank de Araújo, from CMPC, for kindly providing the pictures shown in figure 1.

\section{AUTHOR CONTRIBUTIONS}

Conceptualization: (D) José Miguel Reichert (equal) and (DD Kristiana Fiorentin dos Santos (equal).

Data curation: (D) José Miguel Reichert (equal) and (D) Kristiana Fiorentin dos Santos (equal).

Formal analysis: (D) José Miguel Reichert (equal) and (D) Kristiana Fiorentin dos Santos (equal).

Investigation: (D) José Miguel Reichert (equal) and (D) Kristiana Fiorentin dos Santos (equal). Methodology: (D) José Miguel Reichert (equal) and (D) Kristiana Fiorentin dos Santos (equal).

Project administration: (D) José Miguel Reichert (equal) and (D) Kristiana Fiorentin dos Santos (equal).

Resources: (D) José Miguel Reichert (equal) and (D) Kristiana Fiorentin dos Santos (equal). Software: (D) José Miguel Reichert (equal) and (DD Kristiana Fiorentin dos Santos (equal). Supervision: (D) José Miguel Reichert (equal) and (D) Kristiana Fiorentin dos Santos (equal). Visualization: (D) José Miguel Reichert (equal) and (D) Kristiana Fiorentin dos Santos (equal). Writing - original draft: (D) José Miguel Reichert (equal) and (D) Kristiana Fiorentin dos Santos (equal).

Writing - review \& editing: (D) José Miguel Reichert (equal) and (D) Kristiana Fiorentin dos Santos (equal).

\section{REFERENCES}

Abreu SL, Reichert JM, Reinert DJ. Escarificação mecânica e biológica para a redução da compactação em Argissolo franco-arenoso sob plantio direto. Rev Bras Cienc Solo. 2004;28:519-31. https://doi.org/10.1590/S0100-06832004000300013

Alves AR, Holthusen D, Reichert JM, Sarfaraz Q, Silva LS. Biochar amendment effects on microstructure resistance of a sandy loam soil under oscillatory stress. J Soil Sci Plant Nutr. 2021;21:967-77. https://doi.org/10.1007/s42729-021-00414-2

Ambus JV, Reichert JM, Gubiani PI, Carvalho PCF. Changes in composition and functional soil properties in long-term no-till integrated crop-livestock system. Geoderma. 2018;330:232-43. https://doi.org/10.1016/j.geoderma.2018.06.005

Andrade MLC, Tassinari D, Dias Junior MS, Martins RP, Rocha WW, Souza ZR. Soil compaction caused by harvest and logging operations in eucalyptus forests in coarse-textured soils from northeastern Brazil. Cienc Agrotecnol. 2017;41:191-200. https://doi.org/10.1590/1413-70542017412036216

Awe GO, Reichert JM, Fontanela E. Sugarcane production in the subtropics: Seasonal changes in soil properties and crop yield in no-tillage, inverting and minimum tillage. Soil Till Res. 2020;196:e104447. https://doi.org/10.1016/j.still.2019.104447 
Awe GO, Reichert JM, Holthusen D, Ambus JV, Carvalho PCF. Characterization of microstructural stability of biochar-amended Planosol under conventional tillage for irrigated lowland rice ecosystem. Soil Till Res. 2021;212:105051. https://doi.org/10.1016/j.still.2021.105051

Awe GO, Reichert JM, Timm LC, Wendroth 00. Temporal processes of soil water status in a sugarcane field under residue management. Plant Soil. 2015;387:395-411. https://doi.org/10.1007/s11104-014-2304-5

Baptista J, Levien R. Métodos de preparo de solo e sua influência na erosão hídrica e no acúmulo de biomassa da parte aérea de Eucalyptus saligna em um Cambissolo Háplico da depressão central do Rio Grande do Sul. Rev Árvore. 2010;34:567-75. https://doi.org/10.1590/S0100-67622010000400001

Barrios PG, Pérez Bidegain M, Gutiérrez L. Effects of tillage intensities on spatial soil variability and site-specific management in early growth of Eucalyptus grandis. For Ecol Manag. 2015;346:41-50. https://doi.org/10.1016/j.foreco.2015.02.031

Barros JWD. Planejamento da qualidade do preparo mecânico do solo para implantação de florestas de Eucalyptus spp utilizando o método de desdobramento da função qualidade (QDF) [dissertation]. Piracicaba: Escola Superior de Agricultura "Luiz de Queiroz"; 2001.

Barros NF, Comerford NB. Sustentabilidade da produção de florestas plantadas na região tropical. In: Alvarez VVH, Schaefer CEGR, Barros NF, Mello JWV, Costa LMT, editors. Tópicos em ciência do solo. Viçosa, MG: Sociedade Brasileira de Ciência do Solo; 2002. v. 2. p. 487-592.

Batistão AC, Holthusen D, Reichert JM, Santos LAC, Campos MCC. Resilience and microstructural resistance of Archaeological Dark Earths with different soil organic carbon contents in Western Amazonia, Brazil. Geoderma. 2020;363:e114130. https://doi.org/10.1016/j.geoderma.2019.114130

Braida JA, Bayer C, Albuquerque JA, Reichert JM. Matéria orgânica e seu efeito na física do solo. In: Klauberg Filho O, Mafra AL, Gatiboni LC, editors. Tópicos em ciência do solo. Viçosa, MG: Sociedade Brasileira de Ciência do Solo; 2011. v. 7. p. 221-78.

Braida JA, Reichert JM, Reinert DJ, Sequinatto L. Elasticidade do solo em função da umidade e do teor de carbono orgânico. Rev Bras Cienc Solo. 2008;32:477-85. https://doi.org/10.1590/S0100-06832008000200002

Braida JA, Reichert JM, Reinert DJ, Soares JMD. Coesão e atrito interno associados aos teores de carbono orgânico e de água de um solo franco arenoso. Cienc Rural. 2007a;37:1646-53. https://doi.org/10.1590/S0103-84782007000600022

Braida JA, Reichert JM, Reinert DJ, Veiga M. Teor de carbono orgânico e a susceptibilidade à compactação de um Nitossolo e um Argissolo. Rev Bras Eng Agric Ambient. 2010;14:131-9. https://doi.org/10.1590/S1415-43662010000200003

Braida JA, Reichert JM, Soares JMD, Reinert DJ. Resistência inter e intra-agregados em ensaios de cisalhamento direto de um Nitossolo vermelho distrófico. Rev Bras Cienc Solo. 2007b;31:379-86. https://doi.org/10.1590/S0100-06832007000200020

Braida JA, Reichert JM, Veiga M, Reinert DJ. Resíduos vegetais na superfície e carbono orgânico do solo e suas relações com a densidade máxima obtida no ensaio Proctor. Rev Bras Cienc Solo. 2006;30:605-14. https://doi.org/10.1590/S0100-06832006000400001

Carneiro M, Fabião A, Madeira M. Effects of site tillage and slash management on growth and understory vegetation of Eucalyptus globulus plantations along a rotation time span in Portugal. Eur J For Res. 2014;133:941-55. https://doi.org/10.1007/s10342-014-0812-8

Cavalli JP, Reichert JM, Rodrigues MF, Araújo EF. Composition and functional soil properties of Arenosols and Acrisols: Effects on eucalyptus growth and productivity. Soil Till Res. 2020;196:e104439. https://doi.org/10.1016/j.still.2019.104439

Cavichiolo SR, Dedecek RA, Gava JL. Preparo do solo e o estado nutricional da rebrota de Eucalyptus saligna. Sci For. 2004;66:120-7.

Cavichiolo SR, Dedecek RA, Gava JL. Avaliação do efeito do sistema de preparo em solos de diferentes texturas, na sua resistência mecânica e na produtividade da rebrota de Eucalyptus saligna. Bol Pesq Flor. 2003;47:83-98. 
Cecagno D, Costa SEVGA, Anghinoni I, Kunrath TR, Martins AP, Reichert JM, Gubian, PI, Balerini F, Fink JR, Carvalho PCF. Least limiting water range and soybean yield in a long-term, no-till, integrated crop-livestock system under different grazing intensities. Soil Till Res. 2016;156:54-62. https://doi.org/10.1016/j.still.2015.10.005

Cerdà A, Rodrigo-Comino J, Yakupoğlu T, Dindaroğlu T, Terol E, Mora-Navarro G, Arabameri A, Radziemska M, Novara A, Kavian A, Vaverková MD, Abd-Elmabod SK, Hammad HM, Daliakopoulos LN. Tillage versus no-tillage. Soil properties and hydrology in an organic persimmon farm in eastern Iberian Peninsula. Water. 2020;12:1539. https://doi.org/10.3390/w12061539

Chaer GM, Tótola MR. Impacto do manejo de resíduos orgânicos durante a reforma de plantios de eucalipto sobre indicadores de qualidade do solo. Rev Bras Cienc Solo. 2007;31:1381-96. https://doi.org/10.1590/S0100-06832007000600016

Collares GL, Reinert DJ, Reichert JM, Kaiser DR. Qualidade física do solo na produtividade da cultura do feijoeiro num Argissolo. Pesq Agropec Bras. 2006;41:1663-74.

https://doi.org/10.1590/S0100-204X2006001100013

Dalbem M, Dal'Col J, Sarcinelli TS, Carmo APD. Fomento legal: Cultivando o eucalipto. Aracruz: Pauta; 2008.

Dedecek RA, Curcio GR, Rachwal MFG, Simon AA. Efeitos de sistemas de preparo do solo na erosão e na produtividade da acácia-negra (Acacia mearnsii de Wild.). Cienc Florestal. 2007;17:205-15. https://doi.org/10.5902/198050981952

Dedecek RA, Gava JL. Influência da compactação do solo na produtividade da rebrota de eucalipto. Rev Árvore. 2005;29:383-90. https://doi.org/10.1590/S0100-67622005000300005

Dias Junior MS, Leite FP, Lasmar Junior E, Araújo Junior CF. Traffic effects on the soil preconsolidation pressure due to eucalyptus harvest operations. Sci Agric. 2005;62:248-55. https://doi.org/10.1590/S0103-90162005000300008

Ebling ED, Reichert JM, Peláez JJZ, Rodrigues MF, Valente ML, Cavalcante RBL, Reggiani P, Srinivasan R. Event-based hydrology and sedimentation in paired watersheds under commercial eucalyptus and grasslands in the Brazilian Pampa biome. Int Soil Water Conserv Res. 2021;9:180-94. https://doi.org/10.1016/j.iswcr.2020.10.008

Fasinmirin JT, Reichert JM. Conservation tillage for cassava (Manihot esculenta crantz) production in the tropics. Soil Till Res. 2011;113:1-10. https://doi.org/10.1016/j.still.2011.01.008

Ferreto DOC, Reichert JM, Cavalcante RBL, Srinivasan R. Rainfall partitioning in young clonal plantations Eucalyptus species in a subtropical environment, and implications for water and forest management. Int Soil Water Conserv Res. 2021b;9:474-84.

https://doi.org/10.1016/j.iswcr.2021.01.002

Ferreto DOC, Reichert JM, Cavalcante RBL, Srinivasan R. Water budget fluxes in catchments under grassland and Eucalyptus plantations of different ages. Can J For Res. 2021a;51:513-23. https://doi.org/10.1139/cjfr-2020-0156

Finger CAG, Schumacher MV, Schneider PR, Hoppe JM. Influência da camada de impedimento no solo sobre o crescimento de Eucalyptus grandis (Hill) ex Maiden. Cienc Florest. 1996;6:137-45. https://doi.org/10.5902/19805098332

Fonseca F, Figueiredo T. Effects of site preparation on physical and chemical properties as indicators of forest soil quality. Gaia Sci. 2016;10:38-46. https://doi.org/10.21707/gs.v10.n02a04

Fonseca F, Figueiredo T, Martins A. Survival and early growth of mixed forest stands installed in a Mediterranean Region: Effects of site tillage intensity. For Ecol Manage. 2011;262:1905-12. https://doi.org/10.1016/j.foreco.2011.01.040.

França JS. Preparos do solo para eucalipto em segunda rotação: propriedades físicas e químicas e crescimento inicial [dissertation]. Santa Maria: Universidade Federal de Santa Maria; 2017.

França JS, Reichert JM, Holthusen D, Rodrigues MF, Araújo EF. Subsoiling and mechanical pit-drilling tillage effects on soil physical properties and initial growth of eucalyptus after eucalyptus on steeplands. Soil Till Res. 2021;207:104860. https://doi.org/10.1016/j.still.2020.104860 
Gatto A, Barros NF, Novais RF, Costa LM, Neves JCL. Efeito do método de preparo do solo, em área de reforma, nas suas características, na composição mineral e na produtividade de plantações de Eucalyptus grandis. Rev Árvore. 2003;27:635-46. https://doi.org/10.1590/S0100-67622003000500006

Gonçalves JLM. Cultivo mínimo aumenta produção florestal. Piracicaba: Visão Agrícola; 2009.

Gonçalves JLM, Alvares CA, Higa AR, Silva LD, Alfenas AC, Stahl J, Ferraz SB, Lima WP, Brancalion PHS, Hubner A, Bouillet JPD, Laclau JP, Nouvellon Y, Epron D. Integrating genetic and silvicultural strategies to minimize abiotic and biotic constraints in Brazilian eucalypt plantations. For Ecol Manage. 2013;301:6-27. https://doi.org/10.1016/j.foreco.2012.12.030

Gonçalves JLM, Stape JL, Benedett V, Fessel VAG, Gava JL. Reflexos do cultivo mínimo e intensivo do solo em sua fertilidade e na nutrição das árvores. In: Gonçalves JLM, Benedett V, editors. Nutrição e fertilização florestal. Piracicaba: IPEF; 2000. p. 1-58.

Gonçalves JLM, Stape JL, Laclau JP, Smethurst P, Gava JL. Silvicultural effects on the productivity and wood quality of eucalypt plantations. For Ecol Manage. 2004;193:45-61. https://doi.org/10.1016/j.foreco.2004.01.022

Gonçalves JLM, Wichert MCP, Gava JL, Masetto AV, Arthur Junior JC, Serrano MIP, Mello SLM. Soil fertility and growth of Eucalyptus grandis in Brazil under different residue management practices. South Hem For Sci. 2007;69:95-102. https://doi.org/10.2989/SHFJ.2007.69.2.4.289

Goulart RZ, Reichert JM, Rodrigues MF, Chiaben Neto M, Ebling ED. Comparing tillage methods for growing lowland soybean and corn during wetter-than-normal cropping. Paddy Water Environ. 2021;19:401-15. https://doi.org/10.1007/s10333-021-00841-y

Goulart RZ, Reichert JM, Rodrigues MF. Cropping poorly-drained lowland soils: Alternatives to rice monoculture, their challenges and management strategies. Agric Syst. 2020;177:e102715. https://doi.org/10.1016/j.still.2019.104439

Hakamada RE, Lemos C, Silva RM, Wanderley C. Efeito do método de preparo do solo na produtividade de Eucalyptus grandis x Eucalyptus urophylla em Neossolo quartzarênico e Latossolo. Rev Inst Flor. 2013;25:139-49.

Hamza MA, Anderson WK. Soil compaction in cropping systems: A review of the nature, causes and possible solutions. Soil Till Res. 2005;82:121-45. https://doi.org/10.1016/j.still.2004.08.009

Holthusen D, Brandt AA, Reichert JM, Horn R, Fleige H, Zink A. Soil functions and in situ stress distribution in subtropical soils as affected by land use, vehicle type, tire inflation pressure and plant residue removal. Soil Till Res. 2018a;184:78-92. https://doi.org/10.1016/j.still.2018.07.009

Holthusen D, Brandt AA, Reichert JM, Horn R. Soil porosity, permeability and static and dynamic strength parameters under native forest/grassland compared to no-tillage cropping. Soil Till Res. 2018b;177:113-24. https://doi.org/10.1016/j.still.2017.12.003

Holthusen D, Batistão AC, Reichert JM. Amplitude sweep tests to comprehensively characterize soil micromechanics: brittle and elastic interparticle bonds and their interference with major soil aggregation factors organic matter and water content. Rheol Acta. 2020;59:545-63. https://doi.org/10.1007/s00397-020-01219-3

IUSS Working Group WRB. World reference base for soil resources 2014, update 2015: International soil classification system for naming soils and creating legends for soil maps. Rome: Food and Agriculture Organization of the United Nations; 2015. (World Soil Resources Reports, 106).

Klein VA, Baseggio M, Madalosso T. Indicadores da qualidade física de um Latossolo Vermelho distrófico típico sob plantio direto escarificado. Cienc Rural. 2009;39:2475-81. https://doi.org/10.1590/S0103-84782009005000225

Lima R, Sampietro JA, Bonazza M, Pacheco JM. Influência do preparo de solo no crescimento inicial de Eucalyptus dunnii em Santa Catarina. In: Anais do III Encontro sobre Mecanização, Colheita e Transporte Florestal, 07 a 09 Nov; Lavras MG. Lavras: Universidade Federal de Lavras; 2019. p. 20-6.

Madeira MVA, Melo MG, Alexandre CA, Steen E. Effects of deep ploughing and superficial disc harrowing on physical and chemical soil properties and biomass in a new plantation of Eucalyptus globulus. Soil Till Res. 1989;14:163-75. https://doi.org/10.1016/0167-1987(89)90029-9 
Marins AC, Reichert JM, Secco D, Rosa HA, Veloso G. Crambe grain yield and oil content affected by spatial variability in soil physical properties. Renew Sust Energ Rev. 2018;81:464-72. https://doi.org/10.1016/j.rser.2017.08.003

Milde GA, Dedecek RA, Gava JL. Unidades de colheita: estratégia para evitar a compactação dos solos florestais. Rev Árvore. 2010;34:1075-83. https://doi.org/10.1590/S0100-67622010000600013

Morales CAS. Preparos e atributos físicos de solos para plantio de eucalipto [thesis]. Santa Maria: Universidade Federal de Santa Maria; 2014.

Novara A, Cerdà A, Barone E, Gristina L. Cover crop management and water conservation in vineyard and olive orchards. Soil Till Res. 2021;208:104896. https://doi.org/10.1016/j.still.2020.104896

Novara A, Stallone G, Cerdà A, Gristina L. The effect of shallow tillage on soil erosion in a semiarid vineyard. Agronomy. 2019;9:257. https://doi.org/10.3390/agronomy9050257

Padilha J, Bertol B, Magro BA, Bagio B, Marioti J, Ramos JC. Water erosion under three tillage methods in a cultivation of Eucalyptus benthamii. Rev Árvore. 2018;41:e410606. https://doi.org/10.1590/1806-90882017000600006

Paes FASV, Lima AMN, Hakamada RE, Barros NF. Impacto do manejo dos resíduos da colheita, do preparo do solo e da adubação na produtividade de eucalipto. Rev Bras Cienc Solo. 2013;37:1081-90. https://doi.org/10.1590/S0100-06832013000400025

Pereira DP, Fiedler NC, Lima JSS, Guimarães PP, Môra R, Carmo FCA. Eficiência da subsolagem na profundidade de preparo do solo em função da declividade do terreno. Cerne. 2012;18:60712. https://doi.org/10.1590/S0104-77602012000400010

Bidegain MP, Resquín F, Rachid C. Influence of tillage on some soil chemical properties and Eucalyptus grandis growth. Agrocienc Uruguay. 2012;16:306-9. https://doi.org/10.31285/AGRO.16.688

Prevedello J, Kaiser DR, Reinert DJ, Vogelmann ES, Fontanela E, Reichert JM. Manejo do solo e crescimento inicial de Eucalyptus grandis Hill ex Maiden em Argissolo. Cienc Florest. 2013;23:129-38. https://doi.org/10.5902/198050988447

Prevedello J, Vogelmann ES, Kaiser DR, Fontanela E, Reinert DJ, Reichert JM. Agregação e matéria orgânica de um Argissolo sob diferentes preparos do solo para plantio de eucalipto. Pesq Flor Bras. 2014;34:149-58. https://doi.org/10.4336/2014.pfb.34.78.456

Ramantswana M, Philipe S, Guerra S, Ersson BT. Advances in the mechanization of regenerating plantation forests: A review. Curr For Rep. 2020;6:143-98. https://doi.org/10.1007/s40725-020-00114-7

Reichert JM, Albuquerque JA, Peraza JES, Costa A. Estimating water retention and availability in cultivated soils of southern Brazil. Geoderma Reg. 2020b;21:e00277. https://doi.org/10.1016/j.geodrs.2020.e00277

Reichert JM, Bervald CMP, Rodrigues MF, Kato OR, Reinert DJ. Mechanized land tillage in eastern Amazon in fire-free forest-based fallow systems as alternatives to slash-and-burn practices: Hydraulic and mechanical soil properties. Agr Ecosyst Environ. 2014;192:47-60. https://doi.org/10.1016/j.agee.2014.03.046

Reichert JM, Brandt AA, Rodrigues MF, Reinert DJ, Braida JA. Load dissipation by corn residue on tilled soil in laboratory and field-wheeling conditions: Lab and field load dissipation by soil surface mulch. J Sci Food Agric. 2016a;96:2705-14. https://doi.org/10.1002/jsfa.7389

Reichert JM, Brandt AA, Rodrigues MF, Veiga M, Reinert DJ. Is chiseling or inverting tillage required to improve mechanical and hydraulic properties of sandy clay loam soil under long-term no-tillage? Geoderma. 2017a;301:72-9. https://doi.org/10.1016/j.geoderma.2017.04.012

Reichert JM, Cechin NF, Reinert DJ, Rodrigues MF, Suzuki LEAS. Ground-based harvesting operations of Pinus taeda affects structure and pore functioning of clay and sandy clay soils. Geoderma. 2018a;331:38-49. https://doi.org/10.1016/j.geoderma.2018.06.012

Reichert JM, Corcini AL, Awe GO, Reinert DJ, Albuquerque JA, Gallarreta CCG, Docampo R. Onion-forage cropping systems on a Vertic Argiudoll in Uruguay: Onion yield and soil organic matter, aggregation, porosity and permeability. Soil Till Res. 2022;216:105229. https://doi.org/10.1016/j.still.2021.105229 
Reichert JM, Deus Junior JC, Borges Junior N, Cavalcante RBL. Experimental catchments in the Pampa biome: Database on hydrology in grasslands and eucalyptus plantations in subtropical Brazil. Hydrol Process. 2021e;35:14285. https://doi.org/10.1002/hyp.14285

Reichert JM, Fontanela E, Awe GO, Fasinmirin JT. Is cassava yield affected by inverting tillage, chiseling or additional compaction of no-till sandy-loam soil? Rev Bras Cienc Solo. 2021c;45:e0200134. https://doi.org/10.36783/18069657rbcs20200134

Reichert JM, Mentges MI, Rodrigues MF, Cavalli JP, Awe GO, Mentges LR. Compressibility and elasticity of subtropical no-till soils varying in granulometry organic matter, bulk density and moisture. Catena. 2018b;165:345-57. https://doi.org/10.1016/j.catena.2018.02.014

Reichert JM, Morales CAS, Bastos F, Sampietro JA, Cavalli JP, Araújo EF, Srinivasan R. Tillage recommendation for commercial forest production: Should tillage be based on soil penetrability, bulk density or more complex, integrative properties? Geoderma Reg. 2021a;25:e00381. https://doi.org/10.1016/j.geodrs.2021.e00381

Reichert JM, Morales CAS, Lima EM, Bastos F, Sampietro JA, Cavalli JP, Araújo EF, Srinivasan R. Best tillage practices for early-growth of clonal eucalyptus in soils with distinct granulometry, drainage and profile depth. Soil Till Res. 2021b;212:105038. https://doi.org/10.1016/j.still.2021.105038

Reichert JM, Norton LD, Favaretto N, Huang C, Blume E. Settling velocity, aggregate stability, and interrill erodibility of soils varying in clay mineralogy. Soil Sci Soc Am J. 2009;73:1369-77. https://doi.org/10.2136/sssaj2007.0067

Reichert JM, Pellegrini A, Rodrigues MF, Tiecher T, Santos DR. Impact of tobacco management practices on soil, water and nutrients losses in steeplands with shallow soil. Catena. 2019;183:104215. https://doi.org/10.1016/j.catena.2019.104215

Reichert JM, Prevedello J, Gubiani PI, Vogelmann ES, Reinert DJ, Consensa COB, Soares JCW, Srinivasan R. Eucalyptus tree stockings effect on water balance and use efficiency in subtropical sandy soil. For Ecol Manage. 2021d;497:119473. https://doi.org/10.1016/j.foreco.2021.119473

Reichert JM, Reinert DJ, Suzuki LEAS, Horn R. Mecânica do solo. In: van Lier QJ, editor. Física do solo. Viçosa, MG: Sociedade Brasileira de Ciência do Solo; 2010. p. 29-102.

Reichert JM, Rodrigues MF, Bervald CMP, Brunetto G, Kato OR, Schumacher MV. Fragmentation, fiber separation, decomposition, and nutrient release of secondary-forest biomass, mechanically chopped-and-mulched, and cassava production in the Amazon. Agr Ecosyst Environ. 2015;204:8-16. https://doi.org/10.1016/j.agee.2015.02.005

Reichert JM, Rodrigues MF, Bervald CMP, Kato OR. Fire-free fallow management by mechanized chopping of biomass for sustainable agriculture in eastern Amazon: effects on soil compactness, porosity, and water retention and availability. Land Degrad Dev. 2016b;27:1403-12. https://doi.org/10.1002/ldr.2395

Reichert JM, Rodrigues MF, Peláez JJZ, Lanza R, Minella, JPG, Arnold JG, Cavalcante RBL. Water balance in paired watersheds with eucalyptus and degraded grassland in Pampa biome. Agric For Meteorol. 2017b;237-238:282-95. https://doi.org/10.1016/j.agrformet.2017.02.014

Reichert JM, Rosa VT, Vogelmann ES, Rosa DP, Horn R, Reinert DJ, Sattler A, Denardin JE. Conceptual framework for capacity and intensity physical soil properties affected by short and long-term (14 years) continuous no-tillage and controlled traffic. Soil Till Res. 2016c;158:123-36. https://doi.org/10.1016/j.still.2015.11.010

Reichert JM, Silva VR, Awe GO, Wendroth 00, Srinivasan R. Defining tillage need for edible bean production under no-tillage: Classical and time series analyses. Soil Till Res. 2020a;202:10467. https://doi.org/10.1016/j.still.2020.104671

Reichert JM, Suzuki LEAS, Reinert DJ. Compactação do solo em sistemas agropecuários e florestais: identificação, efeitos, limites críticos e mitigação. In: Ceretta CA, Silva LS, Reichert JM, editors. Tópicos em ciência do solo. Viçosa, MG: Sociedade Brasileira de Ciência do Solo; 2007. v. 5. p. 49-134.

Ribeiro Al. Mecanização no preparo de solo em áreas degradadas por mineração na Floresta Nacional do Jamari (Rondônia - BR) [thesis]. Campinas: Universidade Estadual de Campinas; 2005. 
Richart A, Tavares Filho J, Brito OR, Llanillo RF, Ferreira R. Compactação do solo: Causas e efeitos. Semina Cienc Agrar. 2005;26:321-44. https://doi.org/10.5433/1679-0359.2005v26n3p321

Rosa DP, Reichert JM, Mentges MI, Barros CAP, Reinert DJ, Vieira DA. Cultivo mínimo: efeito da compactação e deformação abaixo da atuação da ponteira do subsolador. Rev Bras Eng Agric Ambient. 2011;15:1199-205. https://doi.org/10.1590/S1415-43662011001100014

Rosa SF, Reinert DJ, Reichert JM, Fleig FD, Rodrigues MF, Gelain NS. Propriedades físicas e químicas de um Argissolo sob cultivo de Eucalyptus dunnii Maiden no Pampa gaúcho. Cienc Florest. 2018;28:580-90. https://doi.org/10.5902/1980509832040

Sampietro JA, Lopes ES, Reichert JM. Compactação causada pelo tráfego de feller buncher e skidder em um Neossolo Regolítico sob distintas umidades. Cienc Florest. 2015;25:239-48. https://doi.org/10.1590/1980-509820152505239

Santos HG, Jacomine PKT, Anjos LHC, Oliveira VA, Oliveira JB, Coelho MR, Lumbreras JF, Cunha TJF. Sistema brasileiro de classificação de solos. 3. ed. Rio de Janeiro:

Embrapa Solos; 2013.

Santos LDT, Ferreira FA, Barros NF, Siqueira CH, Santos IC, Machado AFL. Exsudação radicular do glyphosate por Brachiaria decumbens e seus efeitos em plantas de eucalipto e na respiração microbiana do solo. Planta Daninha. 2005;23:143-52. https://doi.org/10.1590/S0100-83582005000100017

Sasaki CM, Gonçalves JLM. Desempenho operacional de um subsolador em função da estrutura, do teor de argila e de água em três Latossolos. Sci For. 2005;69:115-24.

Secco D, Reinert DJ, Reichert JM, Silva VR. Atributos físicos e rendimento de grãos de trigo, soja e milho em dois Latossolos compactados e escarificados. Cienc Rural. 2009;39:58-64. https://doi.org/10.1590/S0103-84782009000100010

Silva SR, Barros NF, Novais RF, Comerfordd NB. Eucalyptus growth and phosphorus nutritional efficiency as affected by soil compaction and phosphorus fertilization. Commun Soil Sci Plant Anal. 2018;49:2700-14. https://doi.org/10.1080/00103624.2018.1538372

Silva SR, Barros NF, Vilas Boas JEB. Crescimento e nutrição de eucalipto em resposta à compactação de Latossolos com diferentes umidades. Rev Bras Cienc Solo. 2006;30:759-68. https://doi.org/10.1590/S0100-06832006000500001

Silva VR, Reinert DJ, Reichert JM. Fatores controladores da compressibilidade de um Argissolo Vermelho-Amarelo Distrófico arênico e de um Latossolo Vermelho Distrófico típico. II - Grau de saturação em água. Rev Bras Cienc Solo. 2002;26:9-16. https://doi.org/10.1590/S0100-06832002000100002

Silva, VR, Reichert JM, Storck L, Feijó S. Variabilidade espacial das características químicas do solo e produtividade de milho em um Argissolo Vermelho-Amarelo Distrófico arênico. Rev Bras Cienc Solo. 2003;27:1013-20. https://doi.org/10.1590/S0100-06832003000600005

Soares EMB, Teixeira RS, Sousa RN, Vasconcelos AA, Silva IR. Soil organic matter fractions under eucalypt plantation in reform management. Florest Ambient. 2019;26:e20170694. https://doi.org/10.1590/2179-8087.069417

Soil Survey Staff. Keys to soil taxonomy. 12th ed. Washington, DC: United States Department of Agriculture, Natural Resources Conservation Service; 2014.

Stape JL, Andrade S, Gomes AN, Krejci LC, Ribeiro JA. Definição de métodos de preparo do solo para silvicultura em solos coesos do litoral norte da Bahia. In: Gonçalves JLM, Stape JL, editors. Conservação e cultivo de solos para plantações florestais. Piracicaba: IPEF; 2002. p. 259-96.

Suiter Filho W, Rezende GC, Mendes CJ, Castro PF. Efeitos de diversos métodos de preparo de solo sobre o desenvolvimento de Eucalyptus grandis Hill (Ex. Maiden) plantado em solos com camadas de impedimento. Piracicaba: IPEF; 1980.

Suzuki LEAS, Lima CLR, Reinert DJ, Reichert JM, Pillon CN. Condição estrutural de um Argissolo no Rio Grande do Sul, em floresta nativa, em pastagem cultivada e em povoamento com eucalipto. Cienc Florest. 2012;22:833-43. https://doi.org/10.5902/198050987564 
Suzuki LEAS, Lima CLR, Reinert DJ, Reichert JM, Pillon CN. Estrutura e armazenamento de água em um Argissolo sob pastagem cultivada, floresta nativa e povoamento de eucalipto no Rio Grande do Sul. Rev Bras Cienc Solo. 2014;38:94-106. https://doi.org/10.1590/S0100-06832014000100009

Suzuki LEAS, Reichert JM, Reinert DJ, Lima CLR. Degree of compactness and mechanical properties of a subtropical Alfisol with eucalyptus, native forest, and grazed pasture. For Sci. 2015;61:716-22. https://doi.org/10.5849/forsci.14-172

Suzuki LEAS, Reichert JM, Reinert DJ. Degree of compactness, soil physical properties and yield of soybean in six soils under no-tillage. Soil Res. 2013;51:311-21. https://doi.org/10.1071/SR12306

Toit B, Smith CW, Little KM, Boreham GB, Pallett RN. Intensive, site-specific silviculture: Manipulating resource availability at establishment for improved stand productivity. A review of South African research. For Ecol Manag. 2010;259:1836-45. https://doi.org/10.1016/j.foreco.2009.07.015

Valente ML, Reichert JM, Cavalcante RBL, Minella JPG, Evrard O, Srinivasan R. Afforestation of degraded grasslands reduces sediment transport and may contribute to streamflow regulation in small catchments in the short-run. Catena. 2021;204:105371. https://doi.org/10.1016/j.catena.2021.105371

Vaz CMP, lossi MF, Naime JM, Macedo A, Reichert JM, Reinert DJ, Cooper M. Validation of the Arya and Paris water retention model for Brazilian soils. Soil Sci Soc Am J. 2005;69:577-83. https://doi.org/10.2136/sssaj2004.0104

Veiga M, Horn R, Reinert DJ, Reichert JM. Soil compressibility and penetrability of an Oxisol from southern Brazil, as affected by long-term tillage systems. Soil Till Res. 2007;92:104-13. https://doi.org/10.1016/j.still.2006.01.008

Veiga M, Reinert DJ, Reichert JM, Kaiser DR. Short and long-term effects of tillage systems and nutrient sources on soil physical properties of a Southern Brazilian Hapludox. Rev Bras Cienc Solo. 2008;32:1437-46. https://doi.org/10.1590/S0100-06832008000400008

Veiga M, Reinert DJ, Reichert JM. Tillage systems and nutrient sources affecting soil cover, temperature and moisture in a clayey Oxisol under corn. Rev Bras Cienc Solo. 2010;34:2011-20. https://doi.org/10.1590/S0100-06832010000600025

Veiga M, Reinert DJ, Reichert JM. Aggregate stability as affected by short and long-term tillage systems and nutrient sources of a Hapludox in southern Brazil. Rev Bras Cienc Solo. 2009;33:767-77. https://doi.org/10.1590/S0100-06832009000400003

Viera M, Bonacina DM, Schumacher MV, Calil FN, Caldeira MVW, Watzlawick LF. Biomassa e nutrientes em povoamento de Eucalyptus urograndis na Serra do Sudeste-RS. Semina Cienc Agrar. 2012;33:2481-90. https://doi.org/10.5433/1679-0359.2012v33n6Supl1p2481

Weiler DA, Moro VJ, Awe GO, Oliveira DMS, Cerri CEP, Reichert JM, Giacomini J. Carbon balance in sugarcane areas under different tillage systems. BioEnergy Res. 2019;12:778-88. https://doi.org/10.1007/s12155-019-10002-z

Wichert MCP, Alvares CA, Arthur Junior JC, Stape JL. Site tillage, initial growth and soil erosion in Eucalyptus grandis plantations on steep terrain. Sci For. 2018;46:17-30. https://doi.org/10.18671/scifor.v46n117.02

Wohlenberg EV, Reichert JM, Reinert DJ, Blume E. Dinâmica da agregação de um solo franco-arenoso em cinco sistemas de culturas em rotação e em sucessão. Rev Bras Cienc Solo. 2004;28:891-900. https://doi.org/10.1590/S0100-06832004000500011 